\title{
Proposal for suppliers evaluation using the integration of AHP/QFD methods
}

\section{Proposta para avaliação de fornecedores utilizando a integração dos métodos AHP/QFD}

\author{
Juliane Carolina Galiotto ${ }^{1}\left[\mathbb{C}\right.$, Ricardo Augusto Cassel ${ }^{1}$ \\ ${ }^{1}$ Universidade Federal do Rio Grande do Sul - UFRGS, Porto Alegre, RS, Brasil. \\ E-mail: julianegaliotto@hotmail.com; cassel@ufrgs.br
}

How to cite: Galiotto, J. C., \& Cassel, R. A. (2020). Proposal for suppliers evaluation using the integration of AHP/QFD methods. Gestão \& Produção, 27(3), e2178. https://doi.org/10.1590/0104$530 \times 2178-20$

\begin{abstract}
The present work has as main objective the development and presentation of a model for supplier's evaluation. The proposed model includes the criteria of the lean concept and provides a comprehensive analysis for decision-making in the area of supplies. The work involved 05 steps: (i) identify and select the main criteria for lean suppliers management; (ii) perform the weighting of criteria using the AHP (Analytic Hierarchy Process); (iii) define the indicators to be used for the suppliers analysis in every sub-criteria; (iv) calculate the relative weight of each indicator through the analysis of interdependence between the sub-criteria and indicators; (v) testing partially the model through the application of the same in a product group in the reality of a company. The main contribution of this paper is to propose a model that combines the method AHP (Analytic Hierarchy Process) used for multiple criteria decision-making method with QFD (Quality Function Deployment) able to translate these criteria in guidelines for the supply management. From a practical point of view, the importance of this article is to present a relatively simple model for the systematization of building supply indicators. The obtained results recommend the use of this template.
\end{abstract}

Keywords: Supply indicators; Supplier's qualification; Quality function deployment; Hierarchical analytical process.

Resumo: O presente trabalho tem como objetivo principal o desenvolvimento e apresentação de um modelo para a avaliação dos fornecedores. O modelo proposto contempla os critérios do conceito lean sendo que fornece uma análise abrangente para tomada de decisão na área de suprimentos. O trabalho realizado envolveu 05 etapas: (i) identificar e selecionar os principais critérios para a gestão de fornecedores lean; (ii) realizar a ponderação dos critérios através do método AHP (Analytic Hierarchy Process); (iii) definir os indicadores a serem utilizados para a análise dos fornecedores em cada subcritério; (iv) calcular o peso relativo de cada indicador através da análise da interdependência entre os subcritérios e os indicadores; (v) testar parcialmente o modelo através da aplicação do mesmo em um grupo de produtos na realidade de uma empresa. A principal contribuição deste artigo é a proposição de um modelo que combina o método AHP (Analytic Hierarchy Process) utilizada para a tomada de decisão com múltiplos critérios com o método QFD (Quality Function Deployment) capaz de traduzir estes critérios em diretrizes para a gestão do fornecimento. Do ponto de vista prático, a

Received July 1, 2018 - Accepted Dec. 23, 2018

Financial support: None.

This is an Open Access article distributed under the terms of the Creative Commons Attribution License, which permits unrestricted use, distribution, and reproduction in any medium, provided the original work is properly cited. 
importância deste artigo reside no fato de apresentar um modelo relativamente simples para a sistematização da criação de indicadores de fornecimento. Os resultados obtidos recomendam a utilização deste modelo.

Palavras-chave: Indicadores de fornecimento; Índice de qualificação de fornecedores; Desdobramento da função qualidade; Processo analítico hierárquico.

\section{Introduction}

The opening of the markets has increased competitiveness among companies, and their survival, in this new scenario, has made that new postures being adopt. The search for cost reduction and productivity increase has become one of the main objectives of the companies that intend to stay on the market.

The artisan production system was replacing by the mass production system, and later replaced by the Toyota production system created by Taichi Ohno, that broke the paradigms of the Fordist system, such as producing in large lots (Barros et al., 2010). This new system become known as "Toyota production system" or "lean production", and this philosophy extended to companies around the world.

The adoption of this philosophy has brought good results for companies, although few were able to replicate completely the success and operational efficiency achieved by Toyota. The practices were initially employ in the manufacture and, gradually, it has been disseminating in all areas of the company and in different types and sectors, effectively becoming a philosophy and a business culture (Barros et al., 2010).

The dissemination of this practice to all elements of the system bring a new concept: lean. In summary, lean aims reduce waste and, consequently, dropping costs (Yu et al., 2012; Drake et al., 2013; Florent \& Zhen, 2010). Supply Chain Management (SCM) has become, in this context, one of the main factors to increase the competitiveness, and so a primordial factor is the alignment of the strategy lean between all the links of the supply chain. It is on this premise that the suppliers are basing.

It is important that the lean strategy be extend to all departments of the company (Islam \& Rahman, 2013) and that the suppliers be aligned with the work lean strategy adopted by the company. One of the alternatives for aligning suppliers to the company's strategy is create performance indicators that it will define the points to be measured to reach the company 'desired result. According to Ware et al. (2012), companies are increasingly dependent of the suppliers, and their evaluation has become very important for organizational success.

Recognizing the importance of supplier management by the company and the importance of supplier's alignment to lean strategy, this work aims to fill a gap in the literature that consists of a methodology that offers support to defining ways of evaluating and monitor suppliers. Several companies have the suppliers ' manuals with the ways of evaluating them disclosed on their websites. In these manuals, companies disclose monitoring indicators and their influence on the calculation of the Supplier Qualification Index (SQI). However, according to a research carried out by the author, the bibliography covering a method for calculating the Supplier Qualification Index $(\mathrm{SQI})$ is still a poorly explored.

This article aims to contribute with information on criteria, sub-criteria and indicators to evaluate suppliers, using as tools the bibliographic research, applicability observation, company internal research, AHP methods and the matrix of Quality House (HoQ) of the QFD. The main objective of the article was to present a proposal of a 
methodology for defining indicators and its weighting in the composition of the SQI (Supplier Qualification Index).

\section{Theoretical framework}

The theoretical framework of this article is divide into three sections: In the first section, the management of suppliers is discussing in companies with lean philosophy, followed by a review of performance indicators.

The AHP methodology is then approached and subsequently the HOQ/QFD methodology for supplier evaluation.

\subsection{Suppliers management in companies with lean philosophy}

Supplier management is one of the most discussed areas in the supply chain (Plenert, 2007). Companies are pursuing blueprint based on cooperation and long-term alliances (Firmo \& Lima, 2009).

In the same way as supplier management, lean is a management option much used nowadays, and it is composing, in addition to production practices, of supplier relationship programs. In short, the goal of lean is to meet the customers' needs at the highest possible level by eliminating waste (Demeter \& Matyusz, 2011).

It might of course be say, that, the lean system is a set of projects or subprojects that are implement and integrate with the objective of increasing organizational performance (Cardoza \& Carpinetti, 2009). In a lean environment, supply relationships should be based on the long-term focusing on develop programs to improve the cost-quality ratio of the suppliers (Drake et al., 2013).

Amongst the studies done about the supply profile in companies with lean philosophy, we can cite the research of Yu et al. (2012). They advise that manufacturers who provides for lean companies should rationalize the delivery of parts and components so the production will be uninterrupted and the stock levels minimize, thus eliminate waste and optimizing the in-process capital (and therefore efficiency). Suppliers who are in the lean program should focus in times and quantities ordered to ensure they will be feeding the production line at the right time. To achieve this continuous flow of parts, suppliers usually should align their delivery schedule with the buyer's production schedule. This can, however, leads the supplier to have excess stock on hand or have an excessive management control implementation.

Azevedo et al. (2012) highlight that, among the lean supply practices, it can be mention: the sequenced components delivery, the direct delivery at the use point, the geographic concentration, the use of EDI to share information and the use of the main supplier. According to Azevedo et al. (2012), to evaluate the impact of lean in the business development, it can be used the following metrics: 1) Time between the request and the delivery of the order; 2 ) Times required for adjustments; 3 ) The ability to produce what it is needed and when it is needed; 4) Shipments in the requested period and 5) the reduction of the inventory.

The lean philosophy is directly relating to the performance evaluation, which influence the administrative and operational processes of the companies (Cardoza \& Carpinetti, 2009). It is necessary to establish performance measures aligned with lean philosophy, since traditional performance measures do not work in a lean environment (Bhasin, 2012). Lean adopts high-level performance programs (Costa et al., 2014). 


\subsubsection{Importance of performance indicators}

The measurement is the ground to a management system based on indicators, and among the benefits, we can mention the mechanism that generates visibility of performance (Ferreira et al., 2008) and also that enables the company to promote the alignment between its strategic' objectives (Vianna, 2010). However, the measurement requires that the information be express in numbers so that it can be measure and assist in decision-making (Marr, 2009).

The adoption and monitoring of indicators allows verifying the capacity of the system and which levels of performance should be expecting (Senapeschi \& Godinho, 2011). Similarly, once the indicators have been defining, it is already possible to obtain an instrument to promote greater precision to decision making (Vianna, 2010; Weber \& Leite, 2008).

The comparison between actual and goal performance identifies gaps that can indicate a need for an improvement initiative. In addition, the metrics facilitate coordination between the various processes, communicating the performance to the team and managers in the processes (Costa et al, 2014). Since performance measurement is an activity that occurs in a continuous cycle, the action plans refuel the process (Rodrigues \& Sellitto, 2009).

Costa et al. (2014) demonstrate that there is a great relationship between the supplier management practices and the company's performance, since the operational performance of the vendor is strictly link to the company's operational performance.

\subsection{Use of AHP in supplier evaluation}

In the literature, several models have been developing for supplier's evaluation, which use, from weightings, high sophisticate methods with mathematics programming and multi-criteria decision (Viana \& Alencar, 2012). For the accomplishment of the present work, it is used the AHP method developed by Thomas L. Saaty, in 1970, indicated to deal with complex decisions (Ware et al., 2012).

The process of hierarchical analysis is a method that use a reason scale to help people in decision-making. Complex problems are structure, hierarchically, in criteria, sub-criteria and alternatives, from which the choices must be make (Saaty, 1987). AHP is considered a systematic procedure for solving problems and includes subjective and objective measures (Ho et al., 2010), and it make complex decision-making processes more rational by synthesize all available information about the decision in a broad and systematic way (Handfield et al., 2002).

The fundamental premise of AHP is that it can be define, as a hierarchic structure composed of several levels that comprise elements whose characteristics can be consider similar. This type of structuring allows a broad perspective of the entire system and it allows identify the influences among the various elements of the problem, especially where the objective of the decision system consists of alternative's selection considering multiple attributes (lañez \& Cunha, 2006). The top level of the hierarchy represents the overall objective, while the lower level consists in all possible alternatives (Sevkli et al., 2008). So, the more generic the attributes, the higher they should be in the hierarchy (lañez \& Cunha, 2006).

The entry for the model is in the form of matching actions paired between elements (Liu et al., 2008). This comparison uses the principle of logical consistency, which uses the ability of the human to establish relationships between objectives or ideas, in order 
to seek coherence between them, relate them to each other and evaluate the consistency of this relationship. By establishing the parity comparison to ' $n$ ' activities, in order to each one be represented in the data at least once, we need $\mathrm{N}-1$ parity comparisons. The power of the method is in simplifying the work of the mind, through weighting of pair elements (lañez \& Cunha, 2006).

The results show that the method is an important tool of choice, identification of allocation and distribution of priorities (Simões Gomes et al., 2013), being highly flexible and can be applied in a variety of situations with various criteria issues (Chan \& Chan, 2010).

\subsection{Use of quality house matrix (Hoq) in supplier evaluation}

In traditional QFD applications, the company has to identify the expectations of its customers and its relative importance in order to identify for which project characteristics should be allocate more resources. Using the HOQ in the selection and evaluation of suppliers, the company should identify the characteristics that the product/service should have (the expectations of the customer are the expectations of the company itself) and then identify which attributes of suppliers have a greater impact on achieving the established objective (Rajesh \& Malliga, 2013).

The quality house matrix (HOQ- House of Quality) is a universal tool that it can be used to prioritize most tasks in any sector (Rajesh \& Malliga, 2013). Leal \& Pereira (2008) conducted a similar research in which they adapted the quality house to define the supply indicators.

The evaluation and selection of suppliers are considering as a combination between the supplier and company and can be seeing as the House of Quality (HOQ). (Rajesh \& Malliga, 2013).

\section{Methodology}

The work was carry out considering the methodology of the Design Science Research, which aimed to solve a practical problem by constructing an artifact, the application of this artifact in a real environment and the prescription of solutions for problem resolution.

The methodology consists in do a survey of practical or theoretical problem. Then, it raises the organization awareness of its existence and persistence. From this awareness, it is necessary to perform a review in the literature, with the objective of establishing the framework of known solutions. This should consist in the search and identification of artifacts that seek to forward solutions to the problem under discussion (Lacerda et al., 2013).

The research is based on two artifacts, artifact 1 seek to develop a model to define the criteria and its weighting for supplier's evaluation in a company with lean management; artifact 2 uses the model established in artifact 1 to the construction of a new artifact consisting of monitoring indicators definition and their weighting for SQI creation. 


\section{Proposed method}

In this article, we propose the bibliographic research, observation and use of the AHP method together with the QFD for the definition and weighting of performance indicators.

The integration of AHP with the QFD was use by several authors for the definition and weighting of alternatives. Among the uses, it is important to cite the used by Rajesh \& Malliga (2013). These authors used the AHP for weighting the measure's characteristics and the QFD to merge the way it would be measure with the appropriate characteristics. The selection of suppliers would then be complete with the AHP considering the measurement forms and the appropriate weights obtained from the QFD tool.

The work uses part of the method employed by these authors; however, it was adapted for the supplier's evaluation to be monthly perform by the company. Figure 1 presents a proposal of the method.

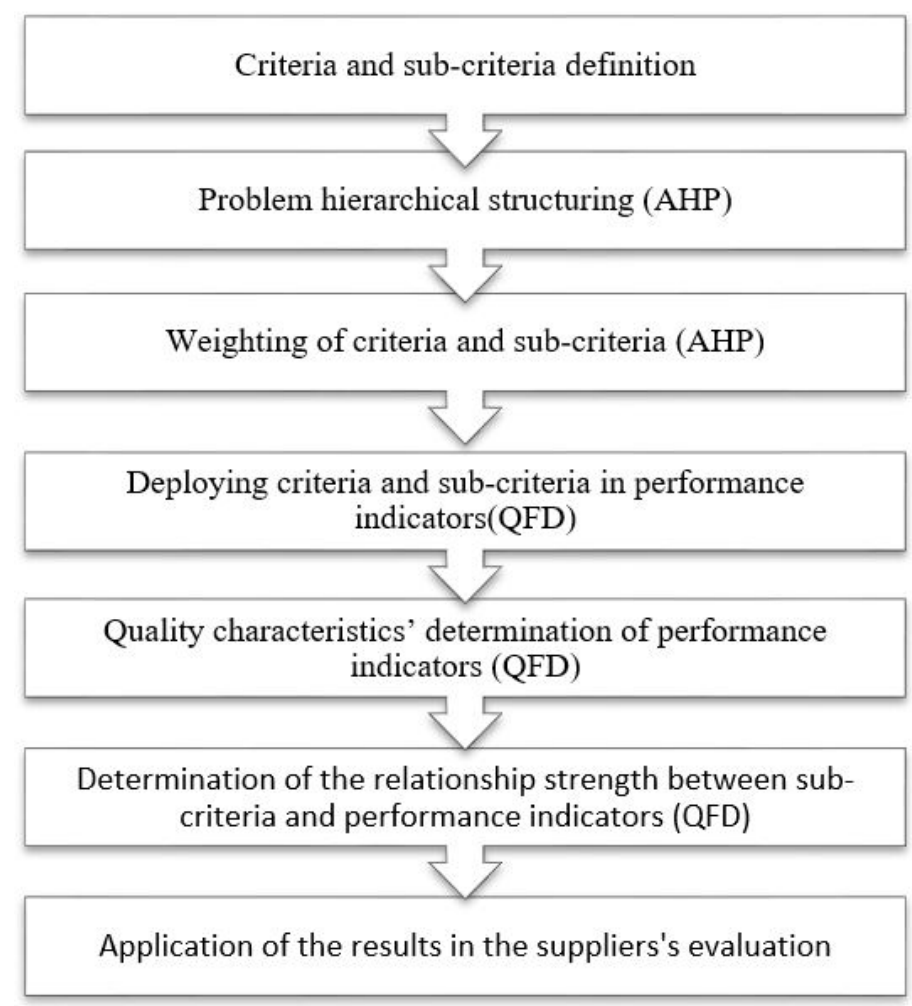

Figure 1. Proposal of a method for SQI creation. Source: Elaborated by the author.

\subsection{Criteria and sub-criteria definition}

The definition of the criteria and sub-criteria have been carry out through the research of the articles published on CAPES website, SCOPUS, plus observations made in the company where the methodology will be applied. Subsequently, the ones with the greatest affinity were group. The general item gives the origin to the criterion and the specific items gives rise to the sub-criteria. The result can be view in Table 1. 
Table 1. Suggestion of criteria and sub-criteria.

\begin{tabular}{|c|c|c|}
\hline Criteria & Sub-criteria & Search sources \\
\hline \multirow{3}{*}{$\begin{array}{l}\frac{\vec{I}}{\sqrt[N]{\sigma}} \\
\frac{\partial}{0}\end{array}$} & - Product quality (specifications). & Drake et al. (2013), Florent \& Zhen (2010). \\
\hline & - Product packaging. & $\begin{array}{l}\text { Note of the company where the methodology } \\
\text { will be apply. }\end{array}$ \\
\hline & - Material expiry date. & $\begin{array}{l}\text { Note of the company where the methodology } \\
\text { will be apply. }\end{array}$ \\
\hline \multirow{4}{*}{ ठั } & - Price. & Chang \& Hung (2010) \\
\hline & - Cost with Reworks. & $\begin{array}{l}\text { Note of the company where the methodology } \\
\text { will be apply. }\end{array}$ \\
\hline & $\begin{array}{l}\text { - Non-fulfillment cost of the } \\
\text { order. }\end{array}$ & $\begin{array}{l}\text { Note of the company where the methodology } \\
\text { will be apply. }\end{array}$ \\
\hline & - Payment term. & Florent \& Zhen (2010). \\
\hline \multirow{7}{*}{$\begin{array}{l}\frac{\lambda}{\Phi} \\
\stackrel{\geq}{\Phi} \\
0\end{array}$} & - Delivery Performance. & Florent \& Zhen (2010). \\
\hline & - Flexibility & Florent \& Zhen (2010). \\
\hline & - Production capacity. & Chang \& Hung (2010) \\
\hline & - Delivery time. & Florent \& Zhen (2010). \\
\hline & - Storage capacity & Chang \& Hung (2010) \\
\hline & - Purchase Lots & Florent \& Zhen (2010). \\
\hline & - Location. & Florent \& Zhen (2010). \\
\hline \multirow{9}{*}{ 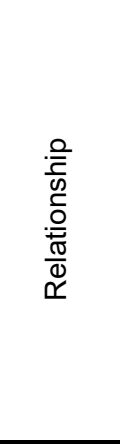 } & - Technological capability. & Chang \& Hung (2010) \\
\hline & - Support Services. & Chang \& Hung (2010) \\
\hline & - Technological capacity. & Florent \& Zhen (2010). \\
\hline & - Communication systems. & Florent \& Zhen (2010). \\
\hline & - Corporate culture & Florent \& Zhen (2010). \\
\hline & - Ability to develop new products & Florent \& Zhen (2010). \\
\hline & - Financial stability & Chang \& Hung (2010) \\
\hline & $\begin{array}{l}\text { - Consistency with strategic } \\
\text { objectives }\end{array}$ & Florent \& Zhen (2010). \\
\hline & - Infrastructure. & Chang \& Hung (2010) \\
\hline
\end{tabular}

Source: Elaborated by the author.

After define the criteria and sub-criteria, it should be make the hierarchical structuring of the problem, in which, the provision of these criteria and sub-criteria should be perform.

\subsection{Problem hierarchical structuring}

This step is very important because it should represent the problem in the best possible way. The items with the highest affinity should be group, and the general item would give rise to the criterion and the specific items would originate the sub-criteria.

\subsection{Weighting of criteria and sub-criteria}

To weigh the criteria and sub-criteria, we suggest the use of the AHP method, and we recommend conducting an internal research with paired comparisons to identify their levels of importance. 
For the elaboration of the comparison matrices, it is considering the main diagonal always as 1 , and for each criteria, there must be reciprocity through the diagonal. The paired comparison matrix between ' $\mathrm{n}$ ' attributes is show in Table 2.

Table 2. Comparison matrix.

\begin{tabular}{ccccc}
\hline Attribute & The $_{1 \mathbf{s t}}$ & $\mathbf{A}_{\mathbf{2}}$ & $\ldots$ & In \\
\hline The $_{1 \mathrm{st}}$ & $\mathrm{X}_{11}=1$ & $\mathrm{X}_{12}$ & $\ldots$ & $\mathrm{X}_{1 \mathrm{n}}$ \\
\hline $\mathrm{A}_{2}$ & $\mathrm{X}_{21}=1 / \mathrm{X}_{12}$ & $\mathrm{X}_{22}=1$ & $\ldots$ & $\mathrm{X}_{2 \mathrm{n}}$ \\
\hline$\ldots$ & $\ldots$ & $\ldots$ & $\ldots$ & $\ldots$ \\
\hline $\mathrm{In}$ & $\mathrm{X}_{\mathrm{n} 1}=1 / \mathrm{X}_{1 \mathrm{n}}$ & $\mathrm{X}_{\mathrm{n} 2}=1 / \mathrm{x}_{2 \mathrm{n}}$ & $\ldots$ & $\mathrm{X}_{\mathrm{nn}}=1$ \\
\hline
\end{tabular}

Source: Kimura \& Suen (2003).

Exemplifying: In the intersection of the line with the column of criterion 1, the score 1 must be include. If the respondent informs that criterion 2 is much less important than criterion 3 , then in the line of criterion 2 with the column of criterion 3 must be listed in the number $1 / 5$ and in the line of criterion 3 with column of criterion 2 must be listed in number 5 .

The mean value of each normalized matrix line is then calculating to obtain the average relative weight of each criteria or sub-criteria.

\subsection{Deploying criteria and sub-criteria in performance indicators}

It should be listed which indicator can best represent it sub-criteria. This definition can be performing together with the company, as well as through bibliographic research. To assist the application of the methodology, Table 3 presents a list of indicators that can be apply for each sub-criteria. This listing was obtaining through bibliographic research, in surveys of sites of companies that have the evaluation procedure of suppliers implemented and in discussions made in the company.

Table 3. Suggestion of indicators for each sub-criteria.

\begin{tabular}{|c|c|}
\hline Sub-criteria & Performance metrics \\
\hline Product quality & $\begin{array}{l}\text { - Supplier Compliance index: reflects the\% of deliveries } \\
\text { according to technical specifications of the product; } \\
\text { - Evaluation of the quality system: reflects the quality } \\
\text { certifications obtained by the supplier; } \\
\text { - Analysis of non-conformities: Non-conformity numbers issued } \\
\text { to the supplier/month; } \\
\text { - Quantity Index: Batches received in the right amount over the } \\
\text { total batches received. }\end{array}$ \\
\hline Shipping packing & $\begin{array}{l}\text { - Packaging Conformity index: reflects the } \% \text { of products } \\
\text { received with packaging conforming considering the total } \\
\text { packaging received. }\end{array}$ \\
\hline $\begin{array}{l}\text { Term material validity } \\
\text { received }\end{array}$ & $\begin{array}{l}\text { - Expiry date: Reflects the\% of products received with an } \\
\text { acceptable shelf life when compared to the total material received. }\end{array}$ \\
\hline Price & $\begin{array}{l}\text { - Cost avoidance: cost reduction in punctual negotiations; } \\
\text { - saving: cost reduction in the purchase of current items; }\end{array}$ \\
\hline Rework Cost & - Rework Value: Cost of supplier goods reworking \\
\hline
\end{tabular}


Table 3. Continued...

\begin{tabular}{|c|c|}
\hline Sub-criteria & Performance metrics \\
\hline $\begin{array}{l}\text { Cost of orders' } \\
\text { non-fulfillment }\end{array}$ & $\begin{array}{l}\text { - Cost due to lack of stock: reflects the margin of the lost sales } \\
\text { value due to material's lack; } \\
\text { - Premium freight: cost with premium freight due to supplier } \\
\text { orders' non-fulfillment. }\end{array}$ \\
\hline Payment term & - Payment Terms: Payment term offered by the supplier. \\
\hline Performance of deliveries & $\begin{array}{l}\text { - Supplier's punctuality index: reflects the } \% \text { of deliveries within } \\
\text { the previously agreed deadline. }\end{array}$ \\
\hline Flexibility & $\begin{array}{l}\text { - Inventory turnover: reflects the amount of times the stock was } \\
\text { use in a given period. }\end{array}$ \\
\hline Production capacity & $\begin{array}{l}\text { - Production capacity: reflects the\% of available capacity that } \\
\text { the supplier has to meet our demand. }\end{array}$ \\
\hline Lead Time & $\begin{array}{l}\text { - Order cycle time: reflects the time between the order date and } \\
\text { the delivery date of the goods. }\end{array}$ \\
\hline Storage capacity & $\begin{array}{l}\bullet \% \text { storage capacity: reflects the } \% \text { of storage capacity that the } \\
\text { vendor has compared to our demand. }\end{array}$ \\
\hline Purchase Lots & $\begin{array}{l}\text { - Purchase lot range: reflects the number in days that the } \\
\text { purchase lot will be in stock considering the material demand. }\end{array}$ \\
\hline Location & $\begin{array}{l}\text { - Transit time: Reflects the number of days from the date the } \\
\text { merchandise was bill and the date it was receive in the company. }\end{array}$ \\
\hline Technological capacity & \multirow{7}{*}{$\begin{array}{l}\text { - Business Relationship Index: Through a questionnaire } \\
\text { assesses technological capacity, financial stability, support } \\
\text { services, level of computerization, communication systems, } \\
\text { corporate culture; ability to develop new products, consistency } \\
\text { with strategic objectives, among others. }\end{array}$} \\
\hline Support Services & \\
\hline Computerization level & \\
\hline Communication systems & \\
\hline Corporate culture & \\
\hline $\begin{array}{l}\text { Ability to develop new } \\
\text { products }\end{array}$ & \\
\hline $\begin{array}{l}\text { Consistency with strategic } \\
\text { objectives }\end{array}$ & \\
\hline Financial stability & $\begin{array}{l}\text { - Financial Stability: Through the analysis of the results } \\
\text { statements, provides a score on the financial stability of the } \\
\text { supplier to fulfill the contract realized. }\end{array}$ \\
\hline Infrastructure & $\begin{array}{l}\text { - Supplier Infrastructure Score: Based on the analysis of the } \\
\text { supplier's infrastructure, provide a score for it. }\end{array}$ \\
\hline
\end{tabular}

Source: Elaborated by the author.

\subsection{Quality characteristics' determination of performance indicators (QFD)}

After defining the indicators, the quality characteristics and grades should being define for each quality characteristic. For measuring indicators, a framework based on the Likert scale was developed (Table 4).

Table 4. Suggestion of notes for supplier evaluation.

\begin{tabular}{cc}
\hline Note & Meaning of note \\
\hline 4 & Ideal condition \\
\hline 3 & Intermediate situation, high enough. \\
\hline 2 & Meets the criteria sufficiently \\
\hline 1 & Intermediate situation, low enough. \\
\hline 0 & It does not have sufficient conditions \\
\hline
\end{tabular}

Source: Elaborated by the author. 
The company must define which would be the ideal condition of supply and, similarly, what other conditions would be consider.

\subsection{Determination of the relationship strength between sub-criteria and performance indicators (QFD)}

As an indicator often has influence in more than one sub-criteria, it should be then determined the relationships between the performance indicators and the supply sub-criteria. For this, it is suggesting the use of the quality house, an existing tool in the QFD method. In the quality matrix line, you must list the delivery sub-criteria and, in the columns, the performance indicators. Items in which there is no correlation should be leave in blank. The score " 9 " should be used when there is a strong relationship between the indicator and the sub-criteria, the score " 3 " when there is a moderate correlation and the score " 1 " when the correlation is weak.

The sub-criteria should be correct by the strategic evaluation (EI) and competitive evaluation (MI). Through a forum involving the management area, it should be defined the relevance that each sub-criteria have in the company's business strategy. Similarly, it should be check the relevance of each sub-criteria in the company's competitiveness.

In the case of the relevance of each sub-criteria in the business strategy, it is suggested the use of Table 5 , which presents a scale to evaluate the sub-criteria in relation to its importance for the company business.

Table 5. Suggestion of importance scale for strategic evaluation (EI).

\begin{tabular}{cc}
\hline Weight & Importance \\
\hline 0.5 & Small \\
\hline 1.0 & Average \\
\hline 1.5 & Great \\
\hline 2.0 & Very large \\
\hline
\end{tabular}

Source: Adapted from Ribeiro et al. (2001).

In the case of the relevance of each sub-criteria in the competitive evaluation, the comparison with the competition should be analyze. In the case of suppliers, the impact that each sub-criteria have on the delivery of the final product should be analyzed compared to the competition. Table 6 presents weighting scales suggested by Ribeiro et al. (2001).

Table 6. Suggestion of importance scale for competitive evaluation (MI).

\begin{tabular}{cc}
\hline Weight & Importance \\
\hline 0.5 & Above competition \\
1.0 & Similar to competition \\
\hline 1.5 & Below the competition \\
\hline 2.0 & Far below the competition \\
\hline
\end{tabular}

Source: Adapted from Ribeiro et al. (2001).

In addition to the sub-criteria, the indicators should also be review, since they must incorporate the performance difficulty (DJ) and the technical benchmarking (BJ). For the analysis of the performance difficulty (DJ), the difficulty in improving the current 
specifications defined by the indicators should be analyze. For this purpose, it is suggested the application of Table 7.

Table 7. Suggestion of importance scale for analysis the difficulty of acting.

\begin{tabular}{cc} 
Weight & Importance \\
\hline 0.5 & Very hard \\
\hline 1.0 & Difficult \\
\hline 1.5 & Moderate \\
\hline 2.0 & Easy
\end{tabular}

Source: Adapted from Ribeiro et al. (2001).

For the technical benchmarking (BJ), we must compare the performance indicators of the company's suppliers to the performance indicators of the competition. It is suggesting use the same indicators as those presented in Table 6 to compare the current standards of the company.

For the calculation of the IDi * (sub-criteria's prioritization), the result of the importance obtained in the application of the AHP method by the square root of the Ei and the square root of the Mi is to be multiplied. The calculations of IQj and IQj * can be visualize in Equations 1 and 2 below:

$$
\begin{aligned}
& I Q_{j}=\sum_{i=1}^{n} I D_{i}^{n} \times D Q_{i j} \\
& I Q_{j}^{*}=I Q_{j} \times \sqrt{D j} \times \sqrt{B j}
\end{aligned}
$$

The last row of the quality matrix demonstrates the desired result: the contribution value of each indicator in the supply qualification index. The application of the result must then be realizing in the comparison of the suppliers.

\section{Results}

In this section is present the result obtained with the application of the proposed method of suppliers' evaluation. The main result is the model with the performance indicators and its weighting in the creation of SQI.

The company in which the method was apply was select due to producing low-tech items and elevating global competition, using lean tools to increase its competitiveness. The alignment of suppliers to their work strategy is very important for their survival.

\subsection{Definition of criteria and sub-criteria}

To enable the implementation of the activity in the company, we sought to work with the indicators that the company already has structure to organize its measurement and, similarly has a greater impact on the company's operating results. The analysis of many sub-criteria increases complexity, which makes execution difficult. 
Therefore, for the first application of the method, it was defined to work with the quality criterion (product quality sub-criteria), Cost (product purchase price and payment term sub-criteria), delivery (delivery time, flexibility and delivery's performance sub-criteria).

\subsection{Hierarchical structuring of the decision problem (AHP)}

The hierarchical structuring of the problem and the disposition of the criteria and sub-criteria is one of the first steps to be follow by the AHP methodology. In the present work, the ranking was performing according to Figure 2. In the basis of the ranking, the criteria of quality, cost and deliveries were considering. Subsequently, the other sub-criteria were distributed.

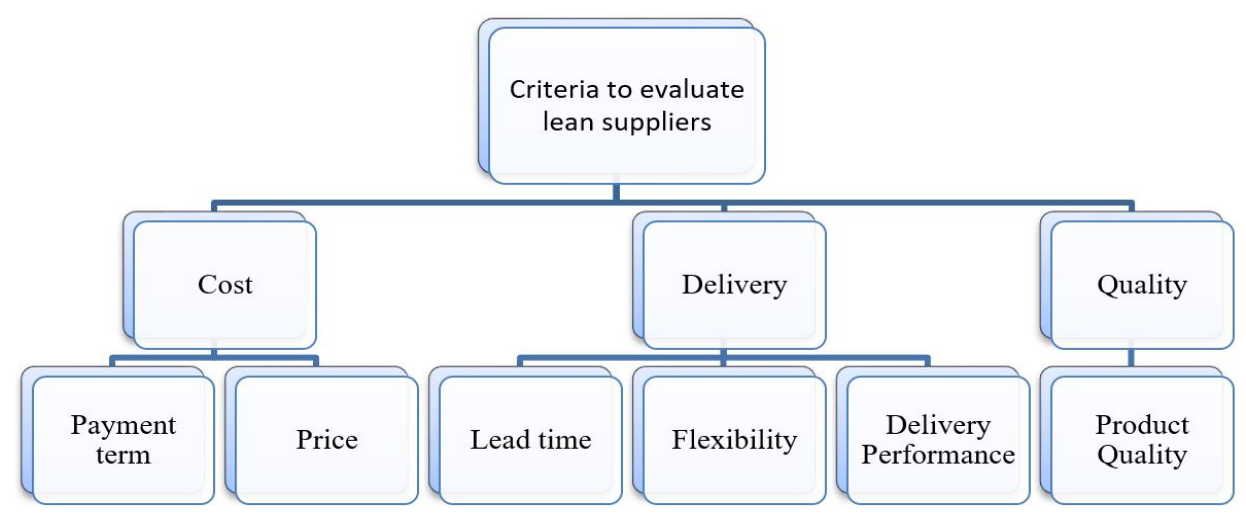

Figure 2. Result of criteria and sub-criteria ranking. Source: Elaborated by the author.

\subsection{Weighting of criteria and sub-criteria (AHP)}

After structuring the problem in criteria and sub-criteria, an internal research was structure to survey its importance according to the perception of the main areas affected by the supplier's performance.

Data collection was carry out through a questionnaire with closed questions, in which the person should respond comparatively to the importance of each criterion and sub-criteria. The AHP was use for tabulation and data analysis. The search results can be view in Table 8.

Table 8. Result of sub-criteria's weight.

\begin{tabular}{cc}
\hline Sub-criteria & Importance \\
\hline Lead Time & $3.41 \%$ \\
\hline Flexibility & $2.18 \%$ \\
\hline Delivery Performance & $13.61 \%$ \\
\hline Price & $24.78 \%$ \\
\hline Payment term & $4.82 \%$ \\
\hline Product quality & $51.19 \%$ \\
\hline
\end{tabular}

Source: Elaborated by the author. 


\subsection{Sub-criteria deployment in performance indicators (QFD)}

The indicators communicate and measure the level of performance required for the company to achieve a goal. In the present study, the objective is to serve as a link between the company and suppliers. Considering the reality of the company in which the study was conduct, the sub-criteria were deployment in the performance indicators as shown in the Table 9.

Table 9. Result with performance indicators for sub-criteria.

\begin{tabular}{ccc}
\hline Sub-criteria & Performance indicator & Unit of Measure \\
\hline \multirow{2}{*}{ Product quality } & Vendor Compliance Index & \\
\cline { 2 - 3 } & Analysis of non-conformities & $\%$ \\
\hline Payment term & Payment term & Days \\
\hline Lead Time & Request Cycle Time & Days \\
\hline Flexibility & Inventory turnover & Days \\
\hline Delivery Performance & Vendor Punctuality Index & $\%$ \\
\hline Price & Saving & $\mathrm{R} \$$
\end{tabular}

Source: Elaborated by the author.

The sub-criteria "delivery performance" can be measure through the cycle time of the order, which is the date on which the order was place until the date the order was deliver to the factory. The sub-criteria "flexibility" can be measure by rotating inventories of the supplier's items, considering the premise that, the greater the flexibility of the supplier to change the quantities and dates of delivery, the greater should be the product stock turnover. The sub-criteria "delivery performance" can be measure by the quantity of items delivered within the deadline requested from the supplier. The price can be analyzing considering the savings obtained by purchasing the product from that supplier. The "payment term" can be analyze considering the payment conditions offered by the supplier. The "product quality" can be evaluate considering the supplier's conformity index, which indicates the percentage of materials delivered in conformity, and the analysis of the non-conformities that it indicates the quantity of non-conformities issued to the supplier.

\subsection{Define the quality characteristics of performance indicators (QFD)}

The company has already registered several quality characteristics, such as delivery time, product purchase price, payment term, percentage of non-conformities, quantity of non-conformities, percentage of lines received on time and inventory turnover. However, this information was not organized, and it was necessary to implement a method to demonstrate its weight in the evaluation of the supplier. Table 10 shows the results of determining quality characteristics. 
Table 10. Result of the value scales for performance indicators.

\begin{tabular}{|c|c|c|c|c|c|}
\hline $\begin{array}{l}\text { Performance } \\
\text { indicators }\end{array}$ & 4 & 3 & 2 & 1 & 0 \\
\hline Order Cycle Time & $<=60$ days & $<=90$ days & $<=120$ days & $<=150$ days & $>=150$ days \\
\hline $\begin{array}{l}\text { Vendor Punctuality } \\
\text { Index }\end{array}$ & $>=99.99 \%$ & $>=98 \%$ & $>=95 \%$ & $>=90 \%$ & $<=90 \%$ \\
\hline Saving & $\begin{array}{c}<=\text { value } \\
\text { previously } \\
\text { defined by } \\
\text { supplies }\end{array}$ & $\begin{array}{c}<=1 \% \text { more } \\
\text { than the } \\
\text { value } \\
\text { previously } \\
\text { defined by } \\
\text { supplies }\end{array}$ & $\begin{array}{c}<=2 \% \text { more } \\
\text { than the } \\
\text { value } \\
\text { previously } \\
\text { defined by } \\
\text { supplies }\end{array}$ & $\begin{array}{c}<=3 \% \text { more } \\
\text { than the } \\
\text { value } \\
\text { previously } \\
\text { defined by } \\
\text { supplies }\end{array}$ & $\begin{array}{c}>=3 \% \text { more } \\
\text { than the } \\
\text { value } \\
\text { previously } \\
\text { defined by } \\
\text { supplies }\end{array}$ \\
\hline Terms of payment & $>=60$ days & $>=30$ Days & $>=15$ days & $>=1$ day & $\begin{array}{l}\text { Advance } \\
\text { payment }\end{array}$ \\
\hline $\begin{array}{l}\text { Vendor Compliance } \\
\text { Index }\end{array}$ & $>=98 \%$ & $>=95 \%$ & $>=93 \%$ & $>=85$ & $<=85 \%$ \\
\hline $\begin{array}{l}\text { Analysis of } \\
\text { non-conformities }\end{array}$ & 0 & $<1$ & $<2$ & $<3$ & $<4$ \\
\hline Stock turnover & $<=30$ days & $<=45$ days & $<=60$ days & $<=75$ days & $>=75$ Days \\
\hline
\end{tabular}

Source: Elaborated by the author.

\subsection{Determination of the relationship strength between performance indicators and supply sub-criteria in a lean environment (QFD)}

At this stage, the QFD HOQ quality house was apply to determine the relationships between performance indicators and supply sub-criteria in a lean environment. In the lines of the quality matrix, the supply sub-criteria defined in the previous step were list, and in the columns, the performance indicators raised above. The correlation between them was make, leaving blank the items in which there was no relation.

The score " 9 " was used when there is a strong relationship between the indicator and the quality criterion, the score " 3 " when there is a moderate relationship and the score " 1 " when the correlation is weak.

The supply sub-criteria were review through the strategic (Ei) and competitive (Mi) evaluation, and the indicators incorporated the performance difficulty (DJ) and the technical benchmarking (BJ) (Table 11). The results can be visualizing in Figure 3.

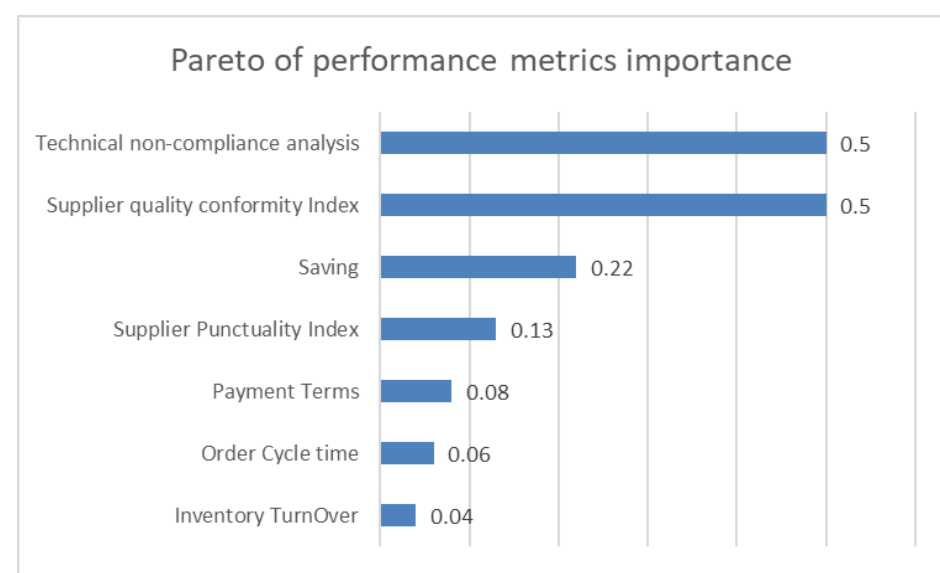

Figure 3. Pareto with the results of importance indicators. Source: Elaborated by the author. 
Table 11. Result of the quality function deployment for supplier management.

\begin{tabular}{|c|c|c|c|c|c|c|c|c|c|c|c|}
\hline \multicolumn{12}{|c|}{ QUALITY MATRIX } \\
\hline $\begin{array}{l}\text { If the } X \\
\text { indicator is } \\
\text { below the } \\
\text { optimum } \\
\text { condition, will it } \\
\text { affect (how?) } \\
\text { on the delivery } \\
\text { criteria? }\end{array}$ & 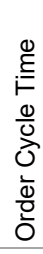 & 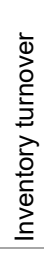 & 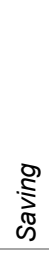 & 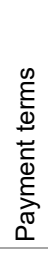 & 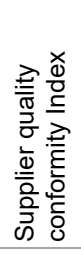 & 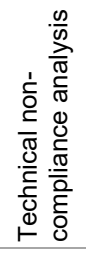 & 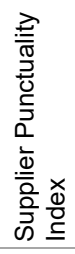 & & & & \\
\hline Criteria & \multicolumn{7}{|c|}{ Indicators } & IDI & EI & MI & IDI \\
\hline Lead Time & 9 & 1 & & & & & 1 & $3.41 \%$ & 0.5 & 1 & $2.41 \%$ \\
\hline Flexibility & 3 & 9 & & & & & 1 & $2.18 \%$ & 0.5 & 2 & $2.18 \%$ \\
\hline Price & & & 9 & 1 & & & & $24.78 \%$ & 2 & 0.5 & $24.78 \%$ \\
\hline Payment term & 1 & 1 & & 9 & & & & $4.82 \%$ & 1.5 & 0.5 & $4.17 \%$ \\
\hline Product quality & & & & & 9 & 9 & & $51.19 \%$ & 2 & 0.5 & $51.19 \%$ \\
\hline $\begin{array}{l}\text { Delivery } \\
\text { Guarantee }\end{array}$ & 1 & 1 & & & 3 & 3 & 9 & $13.61 \%$ & 2 & 0.5 & $13.61 \%$ \\
\hline
\end{tabular}

\begin{tabular}{|c|c|c|c|c|c|c|c|c|}
\hline Specifications & \begin{tabular}{l}
$\infty$ \\
\multirow{\pi}{0}{} \\
$\frac{0}{0}$ \\
0 \\
11 \\
$v$
\end{tabular} & $\begin{array}{l}\text { D } \\
\text { ते } \\
0 \\
0 \\
\text { II } \\
\text { v }\end{array}$ & 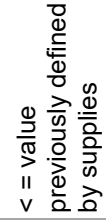 & 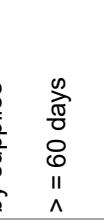 & $\begin{array}{l}\text { ळे } \\
\text { Оे } \\
\text { ळ } \\
\text { II } \\
\text { v }\end{array}$ & $\begin{array}{l}0 \\
\text { II } \\
\text { V }\end{array}$ & $\begin{array}{l}\circ \\
\infty \\
\infty \\
\text { II } \\
1\end{array}$ & \\
\hline IQJ & 0.0460 & 0.0398 & 0.2230 & 0.0623 & 0.5015 & 0.5015 & 0.1271 & \\
\hline Dj & 1.5 & 2.0 & 0.5 & 1.0 & 0.5 & 0.5 & 0.5 & \\
\hline$B \mathbf{j}$ & 1.0 & 0.5 & 2.0 & 1.5 & 2.0 & 2.0 & 2.0 & \\
\hline IQJ* & 0.0564 & 0.0398 & 0.2230 & 0.0764 & 0.5015 & 0.5015 & 0.1271 & 1.53 \\
\hline
\end{tabular}

IDI: Importance of the quality items demanded. El: strategic evaluation. MI: competitive evaluation Source: Elaborated by the author.

\subsection{Application of the results in the evaluation of suppliers of a product group}

In order to test the developed model, the application was make in the evaluation of suppliers for a company's product group. The results of the analysis of the 04 suppliers can be view in the Table 12 .

Table 12. SQI calculation result for a group of suppliers.

\begin{tabular}{lccccc}
\multicolumn{1}{c}{ Indicators } & $\%$ & $\begin{array}{c}\text { Score } \\
\text { Supplier 1 }\end{array}$ & $\begin{array}{c}\text { Score } \\
\text { Supplier 2 }\end{array}$ & $\begin{array}{c}\text { Score } \\
\text { Supplier 3 }\end{array}$ & $\begin{array}{c}\text { Score } \\
\text { Supplier 4 }\end{array}$ \\
\hline Order Cycle Time & 0.0564 & 3 & 3 & 2 & 2 \\
\hline Inventory turnover & 0.0398 & 4 & 3 & 3 & 1 \\
\hline Saving & 0.2230 & 0 & 1 & 4 & 3 \\
\hline Payment terms & 0.0764 & 3 & 3 & 2 & 2 \\
\hline $\begin{array}{l}\text { Supplier quality conformity } \\
\text { Index }\end{array}$ & 0.5015 & 3 & 3 & 4 & 4 \\
\hline $\begin{array}{l}\text { Technical non-compliance } \\
\text { analysis }\end{array}$ & 0.5015 & 3 & 3 & 4 & 3 \\
\hline Supplier Punctuality Index & 0.1271 & 2 & 2 & 4 & 4 \\
\hline SQI & & $\mathbf{3 . 8 2 0 8 5 4 1 6}$ & $\mathbf{4 . 0 0 4 0 5 8 6 8}$ & $\mathbf{5 . 7 9 7 6 3 1 2}$ & $\mathbf{4 . 9 9 3 4 4 0 2 7}$ \\
\hline \% & $63 \%$ & $66 \%$ & $95 \%$ & $82 \%$ \\
\hline
\end{tabular}

Source: Elaborated by the author. 
Multiplying the score obtained by IQJ *, we can observe that supplier 3 obtained the best performance, being the most suitable for the supply of the material and presenting an SQI of 5.7976312. Considering that the maximum score that the supplier can achieve if they obtain all grades equal to 4 is 6.1029066 , the value obtained corresponds to a service percentage of $95 \%$

The supplier 1 analyzed previously is in the phase of disqualification by the company, because in one of the indicators, "saving", did not present sufficient conditions of attendance.

\subsection{Suggestion of results application}

The results reflect the qualification of the suppliers in reaching the requirement of the company. Similarly, the indexes provide guidance for decision-making. This include not only production planning decision but also financial and commercial level decisions.

Therefore, it is suggesting, initially, that the company create and adopt a supplier manual, in order to share its philosophy and work strategy with suppliers. The manual must clearly demonstrate to the suppliers what the company expects of them and how they will be evaluate.

Similarly, it is suggesting that the company carries out a classification of the suppliers considering the SQI calculation. It is important that this classification be publish internally so the decisions are made proactively in order to reduce the impact of the criteria that the suppliers did not have a good performance.

Nevertheless, it is necessary that the company publish these indicators to suppliers, so, they can work on their shortcomings and they can outline strategies to improve indicators in which performance has not reached an ideal condition.

This classification can be used in analyzes of new products supplier development, in improvement programs and corrective actions.

\subsection{Improvements propositions}

Among the propositions of developed method improvement, we can cite:

- Implement a continuous improvement cycle to review the database of criteria, sub-criteria and indicators, through bibliographical research and suggestions from collaborators. This is necessary for the company to become more innovative and competitive, taking advantage of the creativity and knowledge of employees as well as new knowledge disclosed by researchers in bibliographical sources;

- Include the method in a PDCA cycle in order to ascertain whether the criteria, sub-criteria, indicators, quality characteristics and the strength of the relationship of the defined and weighted sub-criteria and indicators has suggested the most suitable supplier for the achievement of company results. In the case of the present work, it is necessary that the company evaluates the results obtained and performs the correction of the failures or deviations found;

- Seek the equalization of the criteria and sub-criteria to avoid highly different score between one sub-criteria and another. One example is the difference between the product quality sub-criteria that was $51.19 \%$ and the term of payment sub-criteria that obtained a score of $4.82 \%$; 
- Analyze the possibility of using quality characteristics, indicators and differentiated sub-criteria for each product group.

\section{Conclusion}

This article presented a proposal for supplier's evaluation in companies that have a lean management philosophy. This proposal is basing on the concepts and methods existing in the literature, as well as, in the analysis and application in a metallurgical company.

It is considering that this model can be apply in most companies, and the weight of the criteria and indicators depends on the strategic position of the corporation. Besides the weights, the criteria and indicators can also change considering the strategy and positioning of the company.

Referring to the proposed method (integrating bibliographic research, analysis of the business environment and hierarchical analytical process (AHP) with the quality matrix of the function deployment (QFD)), it can be concluding that the method is simple and easy and its applicability can be performing in different branches. However, it is required align the criteria and indicators to the branch and strategy of the company.

The presented proposal transposes the difficulties of evaluating suppliers, since it enables the measurement of qualitative factors, it allows the balancing of the conflicting aspects, it allows an evaluation with multiple criteria and it allows appropriate weighting of indicators through the correlated with the evaluation criteria.

Initially, a more detailed and comprehensive analysis of the criteria and applicability of the AHP method was present. The relevance is because the criteria definition is paramount for both selection and supplier evaluation. Subsequently, the focus was on the monthly assessment to be make about the suppliers, sought to identify the indicators to be measure, and weighted by the correlation with the established criteria.

Thus, it can be concluded that the method of the hierarchical analytical process (together with the quality function deployment (QFD) is an appropriate method for the creation of performance indicators and the supply qualification index (SQI).

The following advantages of the proposed model were identifying:

- It is adaptable in companies of different branches;

- Provides a broad view of what the company expects from the supplier;

- Defines a basis for decision-making;

- Supports the best understanding of the company's needs, as well as provides a more detailed evaluation of the supplier;

- Creates synergy between supplier and company, and it is an adequate tool for supplier's development.

In short, it can be concluding that the results obtained in the researches and in the analyses showed that the work met its objective and that a reference model was construct for the creation of the supplier qualification index, based on performance indicators. These indicators allow greater alignment of suppliers to the company's strategy.

The work was limited to proposing a method for evaluating suppliers using as tools the bibliographic research, observation, AHP and QFD methods, since the study has not focused on the strategies of using the SQI within the company and in the same way has not conducted research involve companies from other branches. 


\section{References}

Azevedo, S., Carvalho, H., Duarte, S., \& Cruz-Machado, V. (2012). Influence of green and lean upstream supply chain management practices on business sustainability. IEEE Transactions on Engineering Management, 59(4), 753-765. http://dx.doi.org/10.1109/TEM.2012.2189108.

Barros, L. C., Oliveira, M. B., \& Abrahim, G. S. (2010). A produção enxuta como vantagem competitiva: um estudo de caso do setor automobilístico. In Anais do XXX Encontro Nacional de Engenharia de Produção: Maturidade e Desafios da Engenharia de Produção: Competitividade das Empresas, Condições de Trabalho, Meio Ambiente. Rio de Janeiro: ABEPRO.

Bhasin, S. (2012). Performance of Lean in large organization. Journal of Manufacturing Systems, 31(3), 349-357. http://dx.doi.org/10.1016/j.jmsy.2012.04.002.

Cardoza, E., \& Carpinetti, L. (2009). Indicadores de desempenho para o sistema de produção enxuto. Revista Produção Online, 5(2), 1-13.

Chan, F. T. S., \& Chan, H. K. (2010). An AHP model for selection of suppliers in the fast changing fashion market. International Journal of Advanced Manufacturing Technology, 51(9-12), 1195-1207. http://dx.doi.org/10.1007/s00170-010-2683-6.

Chang, B., \& Hung, H. (2010). A study of using RST to create the supplier selection model and decision-making rules. Expert Systems with Applications, 37(12), 8284-8295.

Costa, J., Rossi, M., Rebentisch, E., Terzi, S., Taisch, M., \& Nightingale, D. (2014). What to measure for success in lean system engineering programs? Procedia Computer Science, 28, 789-798. http://dx.doi.org/10.1016/j.procs.2014.03.094.

Demeter, K., \& Matyusz, Z. (2011). The impact of lean practices on inventory turnover. International Journal of Production Economics, 133(1), 154-163. http://dx.doi.org/10.1016/j.ijpe.2009.10.031.

Drake, P. R., Lee, D. M., \& Hussain, M. (2013). The lean and agile purchasing portfolio model. Supply Chain Management, 18(1), 3-20. http://dx.doi.org/10.1108/13598541311293140.

Ferreira, M. P., Abreu, A. F., Abreu, P. F., Trzeciak, D. S., Apolinário, L. G., \& Cunha, A. A. (2008). Gestão por indicadores de desempenho: resultados na incubadora empresarial tecnológica. Revista Produção, 18(2), 302-318. http://dx.doi.org/10.1590/S010365132008000200008.

Firmo, A. C., \& Lima, R. (2009). Gerenciamento da cadeia de suprimentos no setor automobilístico: um estudo de caso no consórcio modular. Revista Produção Online, 5(4), 866-873.

Florent, T. M., \& Zhen, H. (2010). Study on the supplier evaluation index system of lean supply chain. In Proceedings of the International Conference on e-Education, e-Business, eManagement and e-Learning (IC4E 2010). Los Alamitos: IEEE Computer Society. http://dx.doi.org/10.1109//C4E.2010.23.

Handfield, R., Walton, S. V., Sroufe, R., \& Melnyk, S. A. (2002). Applying environmental criteria to supplier assessment: a study in the application of the analytical hierarchy process. European Journal of Operational Research, 141(1), 70-87. http://dx.doi.org/10.1016/S03772217(01)00261-2.

Ho, W., Xu, X., \& Dey, P. K. (2010). Multi-criteria decision making approaches for supplier evaluation and selection: a literature review. European Journal of Operational Research, 202(1), 16-24. http://dx.doi.org/10.1016/j.ejor.2009.05.009.

lañez, M. M., \& Cunha, C. B. (2006). Uma metodologia para a seleção de um provedor de serviços logísticos. Revista Produção, 16(3), 394-412. http://dx.doi.org/10.1590/S010365132006000300004 . 
Islam, M., \& Rahman, M. (2013). Enhancing lean supply chain through traffic light quality management system. Management Science Letters, 3(3), 867-878. http://dx.doi.org/10.5267/j.msl.2013.01.036.

Kimura, H., \& Suen, A. S. (2003). Ferramentas de análise gerencial baseadas em modelos de decisão multicriterial. RAE Eletrônica, 2(1), 1-19. http://dx.doi.org/10.1590/S167656482003000100008.

Lacerda, D. P., Dresch, A., Proença, A., \& Antunes, J. A. V., Jr. (2013). Design Science Research: método de pesquisa para a engenharia de produção. Gestão \& Produção, 20(4), 741-761. http://dx.doi.org/10.1590/S0104-530X2013005000014.

Leal, J. B. S., \& Pereira, N. A. (2008). Uso do Quality Function Deployment (QFD) na definição do peso das perspectivas e indicadores no Scorecard. In Anais do XXVII Encontro Nacional de Engenharia de Produção. Rio de Janeiro: ABEPRO.

Liu, L. B., Berger, P., Zeng, A., \& Gerstenfeld, A. (2008). Applying the analytic hierarchy process to the offshore outsourcing location decision. Supply Chain Management, 13(6), 435-449. http://dx.doi.org/10.1108/13598540810905697.

Marr, B. (2009). Part II: collecting the right management information: managing and delivering performance (p. 129-133). Oxford: Butterworth-Heinemann. http://dx.doi.org/10.1016/B9780-7506-8710-2.00023-5.

Plenert, G. (2007). What is a supply chain? In G. Plenert (Ed.), Reinventing lean: introducing lean management into the supply chain (Chap. 1, pp. 3-20). Burlington: ButterworthHeinemann. http://dx.doi.org/10.1016/B978-012370517-4/50003-4.

Rajesh, G., \& Malliga, P. (2013). Supplier on AHP QFD methodology. Procedia Engineering, 64, 1283-1292. http://dx.doi.org/10.1016/j.proeng.2013.09.209.

Ribeiro, J. L. D., Echeveste, M. E., \& Danilevicz, A. M. F. (2001). A utilização do QFD na otimização de produtos, processos e serviços (Série Monográfica Qualidade). Porto Alegre: FEENG/PPGEP/UFRGS.

Rodrigues, D. M., \& Sellitto, M. A. (2009). Análise do desempenho de fornecedores de uma empresa de manufatura apoiada em análise de aglomerados. Revista Produção, 19(1), 5569. http://dx.doi.org/10.1590/S0103-65132009000100005.

Saaty, T. L. (1987). Decision making, new information, ranking and structure. Mathematical Modelling, 8, 125-132. http://dx.doi.org/10.1016/0270-0255(87)90555-0.

Senapeschi, A., No. \& Godinho, M., Fo. (2011). A evolução da gestão de compras em uma empresa do segmento de material escolar: estudo de caso longitudinal. Revista Produção, 21(1), 76-93. http://dx.doi.org/10.1590/S0103-65132011005000007.

Sevkli, M., Lenny Koh, S. C., Zaim, S., Demirbag, M., \& Tatoglu, E. (2008). Hybrid analytical hierarchy process model for supplier selection. Industrial Management \& Data Systems, 108(1), 122-142. http://dx.doi.org/10.1108/02635570810844124.

Simões Gomes, C. F., Costa, H. G., \& De Souza, G. G. (2013). Abordagem estratégica para a seleção de sistemas erp utilizando apoio multicritério à decisão. Revista Produção Online, 13(3), 1060-1088. http://dx.doi.org/10.14488/1676-1901.v13i3.1385.

Viana, J. C., \& Alencar, L. H. (2012). Metodologias para seleção de fornecedores: uma revisão da literatura. Revista Produção, 22(4), 625-636. http://dx.doi.org/10.1590/S010365132012005000067.

Vianna, W. B. (2010). Alinhamento estratégico e indicadores de desempenho: um estudo para a integração de processos de gestão da qualidade. Revista Produção Online, 10(1), 26-48. http://dx.doi.org/10.14488/1676-1901.v10i1.211.

Ware, N. R., Singh, S. P., \& Banwet, D. K. (2012). Supplier selection problem: a state-of-the-art review. Management Science Letters., 2(5), 1465-1490. http://dx.doi.org/10.5267/j.msl.2012.05.007. 
Weber, A. C., \& Leite, A. M. S. (2008). Contratação por desempenho em serviços de manutenção: o caso da CST Arcelor Brasil. Revista Produção Online, 8(3).

Yu, M., Goh, M., \& Lin, H. (2012). Fuzzy multi-objective vendor selection under lean procurement. European Journal of Operational Research, 219(2), 305-311.

http://dx.doi.org/10.1016/j.ejor.2011.12.028. 